\title{
Actiniæ collected by the s.s. "Huxley" in the North Sea during the summer of 1907.
}

\author{
By \\ Chas. L. Walton, \\ Assistant Naturalist on s.s. Huxley
}

THE following species were obtained :-

Bolocera tuediae (Johnston).

Bolocera longicornis, Carlgren.

Tealia coriacea (Cuvier).

Rhodactinia crassicornis (O. F. Müller).

Stomphia coccinea (O. F. Müller).

Sagartia undata (O. F. Müller).

S. miniata (Gosse).

S. viduata (O. F. Müller).

S. pallida (Holdsworth).

Sagartia sp.

Chondractinia digitata (O. F. Müller).

Metridium dianthus (Ellis).

Epizoanthus incrustatus (Dub. and Kor.).

Cerianthus lloydii, Gosse.

\section{BOLOCERA TUEDIÆ (Johnst.).}

Voyage XCIII. Station 37. Northumberland ground, 40 fathoms. 1 specimen.

Voyage XCIII. Station 56 . Lat. $55^{\circ} 31^{\prime} \mathrm{N}$. Long. $0^{\circ} 53^{\prime} \mathrm{W}$. 55 fathoms. 2 specimens.

The specimen from 93-37 was young and damaged. Expanse of disk and tentacles in a contracted condition, $30 \mathrm{~mm}$.

Column much contracted and wrinkled, and of a dirty white; outer cycle of tentacles of the same colour, the inner cycles rose-pink. Disk dull uniform pinkish white, mouth the same and protruding, two pink œsophageal grooves. 
Many of the tentacles were missing, especially from the inner cycles; these were three times the length of the outer. The animal, although injured, was still alive when first captured, and the tentacles underwent constant inflation and contraction; during contraction the sulcations showed strongly.

The two examples from Station 56 were large, and in size and colour agreed with the description in Gosse's British Sea Anemones and Corals, p. 186-7. Gosse there writes that the column is "studded somewhat sparsely with minute rounded warts, scarcely apparent when the animal is extended," etc., and also quotes Cocks to this effect; Carlgren, in 1891, discusses the matter, and concludes that the warts described were due to the contraction of the body. wall. In the two examples now under consideration, no warts were to be found when living and expanded, but when preserved and contracted the body wall is thrown into innumerable wart-like folds, which any one who had not seen the animal in a living state might easily take to be genuine warts. The figure on Plate V (of Gosse) certainly does not show a fully expanded specimen, as the tentacles are contracted (for although incapable of retraction they can be considerably contracted). The number of tentacles present in the more perfect specimen amounted to 127 , but so many had been thrown off that anything like an accurate enumeration was impossible.

The internal preservation was bad, but 77 pairs of mesenteries were recognisable.

Measurements fo a preserved specimen:-Breadth of pedal disk, $40 \mathrm{~mm}$. Breadth of oral disk, $50 \mathrm{~mm}$. Height of column, $55 \mathrm{~mm}$. Length of tentacles of the inner cycle, $40 \mathrm{~mm}$., of outer cycle, 15$20 \mathrm{~mm}$. In colour, one approximated very nearly with Gosse's description, but paler; the other very pale, merely tinged with pink and light brown on the inner face of the tentacles, etc. The stomach protruded considerably.

\section{BOLOCERA LONGICORNIS, Carlgren.}

Voyage XC. Station 7. Great Fisher Bank. Lat. $56^{\circ} 59^{\prime}$ N. Long. $2^{\circ} 53^{\prime}$ E. 38 fathoms. 2 specimens.

Voyage XC. Station 10. The Gut. Lat. $56^{\circ} 40^{\prime} \mathrm{N}$. Long. $1^{\circ} 32^{\prime} \mathrm{E}$.

50 fathoms. Abundant, and at other stations in this area.

Voyage XCIII. Station 99 . Lat. $55^{\circ} 48^{\prime} \mathrm{N}$. Long. $0^{\circ} 49^{\prime}$ E. 45 fathoms. 1 specimen.

Voyage XCIII. Station 101. Lat. $55^{\circ} 48^{\prime} \mathrm{N}$. Long. $1^{\circ} 4^{\prime} \mathrm{E} .40$ fathoms, 1 specimen. 
Voyage XCIII. Station 106. Lat. $55^{\circ} 41^{\prime}$ N. Long. $2^{\circ} 13^{\prime}$ E. 43 fathoms. 7 specimens.

Voyage XCVI. Station 1. Lat. $56^{\circ} 0^{\prime} \mathrm{N}$. Long. $3^{\circ} 23^{\prime} \mathrm{E} .38$ fathoms. 4 specimens.

Voyage XCVI. Station 5. Very near last. $27 \frac{1}{2}$ fathoms. 1 specimen.

This species was first described by Carlgren, in 1891, from specimens obtained on the west coast of Sweden, from depths of from 40-80 fathoms. In 1893 he gave a much more detailed account, and mentions the Gullmars-fjord, "other localities on the Swedish west coast," and the Skagerrak as its distribution.

Only a few of those obtained by the s.s. Huxley were in a perfect condition, the best being those taken in the Agassiz trawl during short hauls ; those from beam hauls of several hours' duration being frequently almost destitute of tentacles, which would be found adhering to the mesh in all parts of the trawl.

None of the specimens attained the dimensions of those described by Carlgren, and measurements of fully expanded specimens were not easy owing to the generally great and usually unequal inflation of the body wall. The height of the column varying from 50 to $100 \mathrm{~mm}$. Breadth of oral disk usually equal to the height. Length of inner cycle tentacles up to $80 \mathrm{~mm}$, the outer $25-30 \mathrm{~mm}$.

Pedal disk thin and not well demarcated. None were attached, but were free in the trawl, and only adhered in a slight degree to any vessel in which they were kept, and as they showed no sign of having been torn from any object it is probable that they lie loosely upon the bottom (sandy).

Column smooth and polished and thin, finely wrinkled when contracted. Tentacles 160 , in six cycles in the larger specimens, stout, tapering to the tip, strongly sulcated, fairly contractile, constricted at the base, and very readily thrown off. Disk smooth, two large œsophageal grooves, stomach freely protruded and grooved.

Some few were of the colours described by Carlgren, "flesh colour all over, tentacles often brown-red on the inner side, gonidial-tubercles and primary mesenteries weak carmine." But the majority had the column chestnut or dull orange (the mesenteries showing as faint white lines during distention)

Tentacles maroon or, rarely, chestnut, the inner faces much darker than the outer, and the inner cycles darker than the outer. Disk a warm flesh tint, or light orange-brown, with numerous irregular radial lines of dark brown or maroon, of varying widths, but widest and darkest about the base of the tentacles. CEsophageal grooves flesh colour. Throat and stomach brownish pink. The colours persist well 
in preserved specimens. B. longicornis is not easy to keep alive, and soon after capture usually protrudes the stomach walls to an enormous extent, collapses to an abject flatness and dies.

\section{RHODACTINIA CRASSICORNIS (O. F. Müller).}

In 1902, O. Carlgren, in his paper on the Actiniæ of the Olga expedition considered that the name Urticina (Tealia) crassicornis really covered three species belonging to two genera, i.e., Rhodactinia crassicornis (O. F. Müll.), Tealia coriacea (Cuv:), and Tealia lofotensis (Dann.).

Unfortunately I did not see this paper until after the voyages, and regarded all the forms obtained as varieties of Urticina crassicornis. merely making notes on colour and external characters at the time of capture. In these notes I however distinguished three forms: $(\alpha) U$, crassicornis, the normal form of the littoral area ; $(b)$ the large deep-water form, the Tealia tuberculata of Cocks and Cunningham, and (c) a form with small warts, occurring on the Great Fisher Bank. A subsequent anatomical examination of such specimens as were preserved shows this last to be $R$. crassicornis and the other two to be forms of $T$. coriacea. It is thus almost impossible to assign all the numerous records to their real species, only those cases where my notes actually notice the size of the warts and the preserved specimens can be safely noticed.

R. crassicornis occurred at several stations during Voyage $\mathrm{XC}$ about the region of the Great Fisher Bank, together with B. longicornis and Chondractinia digitata.

Almost all the specimens were large, having an expanse of from 12 to $14 \mathrm{~cm}$. They were attached to valves of Cyprina islandica and Modiola, both dead and living, and Fusus antiquus, either living, empty, or tenanted by Eupagurus bernhardus, and once upon the shell of a living $F$ : turtonis.

The small warts which beset the upper part of the column are arranged in irregular vertical rows, and during partial contraction the arrangement frequently appears annular. The colouration is very variable; the following were noted:-

(a) Much resembles Gosse's description and plate of Bolocera eques. The margin was frequently not retracted, even when the tentacles had been withdrawn. The disk, however, was never "pellucid," nor was the scarlet tentacular ring bounded by white, as described by Gosse.

When I first saw this I took it to be $B$. eques.

(b) Column dull orange, the summit white. Tentacles dull pink, the scarlet ring indistinct. Disk pale orange. 
(c) Like the last, but the disk dull pink, and the mouth area vivid rose-red.

(d) Column as (a). Disk dull white, smudged with yellow. Tentacles a fine rose-red, inner faces darkest, scarlet ring not distinguishable, basal lines chestnut.

(e) Column as $(a)$. Disk red. Tentacles with an indistinct white ring, no scarlet band.

$(J)$ Column dull orange, summit red, the fosse blue. Disk cobalt blue, two red circles around the mouth. Tentacles dull orange-brown, red ring well defined, basal lines faint.

In others the column was blotched with scarlet.

In all cases the warts were white. The stomach frequently everted to a considerable extent.

The food of this species appeared to be varied, a full-sized Spatangus purpureus and larger shells of Cardium and Psammobia were ejected after capture, and considerable masses of Tubularia, though this may have been obtained in the trawl. Those kept alive swallowed Dendronotus arborescens with avidity, but refused Tritonia hombergi.

\section{TEAIIA CORIACEA (Cuvier).}

The large deep-water form, described as Actinia tuberculata by Cocks and Tealia tuberculata by Cunningham, was obtained from various localities.

The colours are generally pale and the warts on the column large. The tentacles 160 in number; in several there was a bifurcation of one or more.

Usually attached to shells (dead). Near the coast, in shallow water, specimens resembling the ordinary shore form were obtained.

STOMPHIA COCCINEA (O. F. Müller).

Actinia coccinea, Müller, 1776.

Stomphia churchice, Gosse, 1859.

Stomphia coccinea, Carlgren, 1893 and 1902.

Voyage XCIII. Station 47. Off Seaham. 14 fathoms. 1 specimen.

Voyage XCIII. Station 65 . Lat. $55^{\circ} 35^{\prime} \mathrm{N}$. Long. $0^{\circ} 50^{\prime} \mathrm{W} .45$ fathoms.

6 specimens.

Voyage XCIII. Station 73 . Lat. $55^{\circ} 39^{\prime} \mathrm{N}$. Long. $1^{\circ} 10^{\prime} \mathrm{W} .50$ fathoms. 7 specimens.

Voyage XCIII. Station 75. Near the last. 50 fathoms. 11 specimens. 
Voyage XCIII. Station 77. Off Holy Island. 32 fathoms. Common. Voyage XCIII. Station 82. Off St. Abbs. 37 fathoms. 1 specimen. Voyage XCIII. Station 83 . Lat. $56^{\circ} 7^{\prime} \mathrm{N}$. Long. $1^{\circ} 22^{\prime} \mathrm{W}$. 42 fathoms. 1 specimen, and at a number of other stations in that area a few specimens, or common.

Voyage XCIV. Station 23. Lat. $53^{\circ} 49^{\prime}$ N. Long. $0^{\circ} 15^{\prime}$ E. 15 fathoms. 1 specimen.

Voyage XCVI. Station 20. Lat. $54^{\circ} 11^{\prime} \mathrm{N}$. Long. $1^{\circ} 40^{\prime} \mathrm{E} .22$ fathoms. 1 specimen.

Adhering to stones and dead shells. Several from 93-77 were upon living shells of Aporrhais pes-pelecani, the dead shells used were usually Modiola modiolus and Psammobia ferronsis, etc. In confinement this species displays much restlessness, detach themselves and roll about the vessel or tank, re-attach and again loosen, and so on, also as Gosse observes (p. 222), "very protean in shape," and frequently assumes the shape shown in Gosse's figure (Pl. VIII).

Colours very variable; the column is always smooth, and has a satiny lustre, the crimson or yellowish white predominating according to the individual. Disk dull red or white, streaked with red; lips usually crimson; throat dull white or pink. In some specimens a circle of dull spots upon the inner third of the disk. Esophageal grooves, two, red.

The pedal disk is frequently flecked and streaked with red of considerable intensity; this is probably corellated with the habit of living for varying periods unattached, lying on the side on hard rocky ground such as it favours. The tentacles pellucid white, with one or two bright red rings, or only one ring near the tip; sometimes the rings are indistinct or a white ring below the red ones. Red lines frequently run down the sides of the tentacles on to the disk. In some also a white spot is present at the base of each tentacle of the two inner cycles, thus forming two alternate circles of white spots. In several, from XCIII. 90, the column and disk were very pale and almost transparent, but the tentacles and throat were red.

It was noticeable that when a series of stations was worked at intervals away from the coast (Northumberland), the colours of this spe zies became more and more faint, until the column was so transparent that the mesenteries could be counted with ease.

SAGARTIA UNDATA (O. F. Müller).

Actinia undata, Müller, 1788. Zool. Danica.

Sagartia troglodytes, Gosse, P. H., 1860.

Cylista undata, Andres, 1883.

Sagartia undata, Carlgren, O., 1893. 
Voyage XCV. Station 24. S. edge of Coal Pit. 13 fathoms. 1 specimen.

A small specimen attached to a stone among Serpula and Balanus, and only visible when elongated and expanded.

Column cylindrical pink, white longitudinal lines near the base, some sand attached. Disk pure satiny white. Mouth flat, throat buff. Tentacles 70-80, not very long, yellowish white, barred transversely, some with two ill-defined dark lines upon the front face, and a rather prominent B mark at the foot.

SAGARTIA VIDUATA (O. F. Müller).

Voyage LXXXIX. Station 22. Lat. $54^{\circ} 28^{\prime}$. Long. $2^{\circ} 36 \frac{1}{2}^{\prime}$ E. 18 fathoms. 1 specimen.

Voyage XC. Station 2. Off Esbjerg. Lat. $55^{\circ} 22 \frac{5}{8}^{\prime}$ N. Long. $8^{\circ} 10 \frac{1}{2}^{\prime} \mathrm{E}$. 8 fathoms. Several specimens.

Voyage XCII. Station I0. Lat. $54^{\circ} 0^{\prime}$ N. Long. $6^{\circ} 46 \frac{3^{\prime}}{4} \mathrm{E} .16$ fathoms. 6 or 7 specimens.

Voyage XCII. Station 28. Lat. $54^{\circ} 51^{\frac{1}{2}}$. Long. $6^{\circ} 38^{\prime}$ E. 22 fathoms. Common.

Voyage XCII. Station 31. Lat. $54^{\circ} 47 \frac{7}{8}^{\prime}$. Long. $6^{\circ} 30^{\prime}$ E. 21 fathoms. Abundant.

Voyage XCII. Station. 34. Lat. $54^{\circ} 2^{\prime}$. Long. $6^{\circ} 54^{\prime} \mathrm{E} .14$ fathoms. Several.

Voyage XCII. Station 42. Lat $54^{\circ} 23^{\prime}$. Long. $7^{\circ} 47^{\prime}$ E. 12 fathoms. Fairly common.

Voyage XCIV. Station 54. Sole Pit. 47 fathoms. 2 specimens.

Voyage XCIV. Station 56. Sole Pit. 45 fathoms.

Voyage XCVI. Station 15 . Lat. $54^{\circ} 30^{\prime} \mathrm{N}$. Long. $3^{\circ} 59^{\prime} \mathrm{E} .25$ fathoms. Fairly common.

Voyage XCV1. Station 17. Lat. $54^{\circ} 20^{\prime} \mathrm{N}$. Long. $1^{\circ} 43^{\prime}$ E. 24 fathoms. 1 specimen.

Upon stones, valves of Ostrea, lumps of slag and one from 89-22 in a hollow on a lump of "Moorlog," also inside empty shells of Buccinum.

Colours, etc., as described by Gosse, Carlgren and others, those from more than 40 fathoms paler than usual.

SAGARTIA MINIATA (Gosse).

Voyage XCII. Stàtion 28. Lat. $54^{\circ} 51 \frac{1}{2}^{\prime}$. Long. $6^{\circ} 38^{\prime}$ E. 22 fathoms. $8-9$ specimens.

Voyage XCIII. Station 27. Off Whitby. 25 fathoms.

Voyage XCIV. Station 54. The Sole Pit. 47 fathoms. 5 specimens, and at four other stations in the same area, common. 
Voyage XCV. Station 7 Smith's Knoll, L. V. 26 fathoms. 5 specimens. Voyage XCV. Station 20. Knoll Deep. 22 fathoms. 4 specimens.

Voyage XCV. Station 24. S. edge of the Coal Pit. 13 fathoms. Fairly common.

Voyage XCVI. Stations 15 and 16 . Lat. $54^{\circ} 30^{\prime} \mathrm{N}$. Long. $3^{\circ} 59^{\prime} \mathrm{E}$. 25 fathoms. Very common.

Voyage XCVI. Station 17. Lat. $54^{\circ} 20^{\prime}$ N. Long. $1^{\circ} 43^{\prime}$ E. 24 fathoms. Fairly common.

Voyage XCVI. Station 18. Lat. $54^{\circ} 20^{\prime}$ N., near Long. $1^{\circ} 43^{\prime}$ E. 24 fathoms. One or two.

This species usually occurs in colonies upon living and dead Ostrea, frequently clustered about the base of a colony of Alcyonium digitatum (growing on the Ostrea also), their bases overlapping or overlapped by the edge of the colony of $A$. digitatum, and often with $S$. viduata.

The colour as a rule is very variable, particularly as regards the outer cycles of tentacles, the "core" of these, though generally scarlet, may be orange-red, faint orange, or without any difference in colour from the inner cycles. Disk also variable, each colony usually being fairly uniform as to the colour of the outer tentacles and the number of the "gonidial" radii, one colony of 7 (from 96-15) having one very broad white radius each, and the same occurred in a colony of $S$. viduata from the same station.

Those procured in the Coal Pit in from 42 to 47 fathoms, bottom black mud, were identical in colouring (and as bright in colour) as those abundant in rock pool at low tide at East Hartlepool.

SARGARTIA PALIIDA, var. RUFA (Holdsworth).

Voyage XCVI. Station 15. Lat. $54^{\circ} 30^{\prime} \mathrm{N}$. Long. $3^{\circ} 59^{\prime} \mathrm{E} .25$ fathoms. 8 or 9 specimens.

This colony was attached to a valve of Ostrea, together with young Metridium dianthus, to which, when contracted, they bore a strong superficial resemblance, and where that species is abundant would be easily passed over as the young form of one of the colour varieties.

Size of largest specimens.-Expanded diameter, $20 \mathrm{~mm}$. Height, $15 \mathrm{~mm}$. Length of tentacles of inner cycles, $10 \mathrm{~mm}$. Column smooth and of a uniform dull orange-brown. Base somewhat spreading. Disk dusky white, mouth and throat orange ribbed. Tentacles numerous, about 200 in 5 (?) cycles, a double white spot at the base, which is also encircled by bowed bluish black lines; these lines give the disk a dusky appearance, and show through the body wall when contracted as a broad blackish band. One very young specimen had the column orange in colour and only eight tentacles; another, somewhat larger, 
24 tentacles. In the first of these the basal lines were not visible; in the one with 24 tentacles they were blue, and the tentacles had a faint white core.

Acontia were emitted from both mouth and column.

These larger specimens were much more robust and darker in colour than any I have seen on the English or Welsh coasts; in such the column is generally white or pale orange (as in the young form described above), and the basal lines blue or purple.

With the exception of this species (and the next to be described) the anatomy of most of the forms obtained by the Huxley is well known. An attempted investigation of this species ended in failure; the tissues were hard and brittle, due to preservation in too high a percentage of formalin. The external form and colour were excellently preserved however. It would be well when several specimens are obtained to preserve those intended for anatomical purposes in alcohol, and museum specimens in formalin.

\section{SAGARTIA SP.}

Voyage XCIV. Station 56. The Sole Pit. Lat. $53^{\circ} 36^{\prime}$ N. Long. $1^{\circ} 30^{\prime} \mathrm{E}$. 45 fathoms. 1 specimen.

Attached to a dead valve of Ostrea. Expanded diameter, $25 \mathrm{~mm}$. base slightly exceeding the column, outline irregular and lobed. Column firm, much wrinkled during contraction, slightly so when expanded. The summit smooth, margin tentaculate; a few weak suckers on the upper parts of the column. Colour of column dull white, the mesenteries showing as white longitudinal lines, especially about the base.

Disk transparent white, the mesenteries showing as numerous white radial lines; mouth large and frequently gaping; lips lobed, yellowish; throat brownish buff.

Tentacles about 96 in number, thick and swollen at the base, tapering gradually to the tip, white (showing an irregular white core during contraction), with a faint lilac tinge, stronger upon the lower parts and most pronounced during contraction. During complete contraction the tentacles show through the column wall as a broad lilac or light purple area. Examination with a lens showed this colour to occur upon the tentacle in little streaks. Acontia sparingly emitted and only after severe irritation. Much flattened upon complete contraction. I am not aware of any species of the genus to which I can safely refer this form, but it appears to be nearly allied to $S$. miniata; further material may provide additional evidence and permit of the form being examined anatomically. 


\section{CHONDRACTINIA DIGITATA (O. F. Müller).}

Occurred frequently in abundance at many stations in the region of the Great Fisher Bank and about Lat. $55^{\circ} 31^{\prime}$ N., Long. $0^{\circ} 53^{\prime}$ W.; $55^{\circ}$ $48^{\prime}$ N., $0^{\circ} 49^{\prime}$ E.; $55^{\circ} 44^{\prime}$ N., $1^{\circ} 40^{\prime}$ E., and many other stations in those areas in from 34 to 55 fathoms.

Generally attached to the shells of various species of Fusus, either living or inhabited by Eupagurus bernhardus. Those from the Great Fisher Bank showed great variability in the size of the warts and colour of the column, etc. ; there might be but one row of prominent warts near the summit, or they might be scattered thickly over the greater part of the column, and the colour of the column varied from dirty white to dull orange, and the tentacles from dull pale lilac to light brown.

In a few there was a tendency to mammillation in the warts thus approaching $C$. nodosa, though none could be placed in that species. Carlgren mentions similar cases, but in a region where both forms were to be found. $\mathrm{He}$ found it difficult to determine to which species some individuals should be assigned.

\section{METRIDIUM DIANTHUS (Ellis).}

This species was found so constantly and abundantly throughout the entire area investigated, as to render an enumeration of localities unnecessary. All the colour varieties mentioned by Gosse, Carlgren, and others were represented, with the exception of the sulphur and lemonyellow; this appears to be somewhat rare (it is abundant in places on the coast of N. Wales). The most frequent in the North Sea is a dirty white, especially in the deeper water. Carlgren (1893, p. 102) says “Die rein weisse Varietat" (var. sidonea, Gosse, 1860, p. 13) " habe ich nur in tiefem Wasser angetroffen." In shallower areas the red, pink, and pale orange are abundant; the dark brown and olive forms were only taken occasionally.

This species is to be found attached to stones, wood, Algœ, Alcyonidium gelatinosum, Buccinum, Fusus (in such it usually occupies the apical region), upon the surface of Cancer pagurus, etc., etc. I have seen a large female Cancer almost entirely covered by an enormous red anemone.

Pycnogonim littorale is frequently to be found clinging about the base of this species, and on several occasions I have observed it feeding upon this and other species. The proboscis is sunk deeply into the tissues, and the claws are hooked into the body wall. It requires a sharp pull to draw out the proboscis, and the tissues around the puncture were generally discoloured, showing the proboscis to have 
remained inserted for some considerable time. $P$. littorale was observed feeding in a similar manner upon Chondractinia digitata in the region of the Great Fisher Bank, and Sagartia miniata from the Sole Pit, neither the tough body wall in one case nor the acontia in the other being sufficient protection. The coloured tissues of the anemone were often visible within the body and proboscis of the Pycnogonum, and that these attacks may prove fatal to young Actinians was observed in my aquaria in the spring of 1907 at Newquay, in Cornwall, a young Sagartia being speedily killed, and young Bunodactis thallia (Gosse) were much injured.

I have since seen it feeding upon Actinia equine, Linn., and young $M$. dianthus in the Plymouth aquaria.

\section{EPIZOANTHUS INCRUSTATUS (Diib. and Kor.).}

Voyage XCIII. Station 34. East of Shields. 38 fathoms. Common. Voyage XCIII. Station 37. Northumberland ground. 40 fathoms. 5 specimens.

Voyage XCIII. Station 59. Lat. $55^{\circ} 31^{\prime}$ N., $0^{\circ} 36^{\prime}$ W. 47 fathoms. Common, and a number of other stations in that area in 40 to 57 fathoms.

The colonies varied greatly in size, number of polyps, etc. All were incrusting forms, forming carcinæcia by replacement of the shells of gastropod shells; the carcinæcia were inhabited by various species of Eupagurus. The smallest colony consisted of 4 polyps. The largest obtained measured $42 \mathrm{~mm}$. in length, and the polyps varied from $12 \mathrm{~mm}$. in height and $7 \mathrm{~mm}$. in breadth to $6 \mathrm{~mm}$. by $4 \mathrm{~mm}$.

The number of polyps in a colony was usually 10 , but as many as 30 were counted in one case, many of these being, of course, mere buds.

The incrustations were extremely dense, the ectoderm and mesoglœa being permeated with sand, and there was usually a considerable amount in the cœlenteron. Repeated attempts to observe the polyps expanded all failed, owing to the motion of the ship, the animals being very timid.

\section{CERIANTHUS LLOYDII, Gosse.}

Voyage XCIII. Station 36. East of Shields. 38 fathoms. 2 specimens.

Voyage XCIII. Station 39. Northumberland ground. 34 fathoms. 1 specimen.

Voyage XCIII. Station 70 . Lat. $55^{\circ} 39^{\prime}$ N. Long. $1^{\circ} 10^{\prime}$ W. 50 fathoms. 1 specimen.

Of these only the last was in a sufficiently good condition to be of use, the others were badly injured by the trawl. 
Length when living, $60 \mathrm{~mm}$. In spirit, $27 \mathrm{~mm}$.

Column cylindrical, tapering gradually posteriorly.

Body wall transversely wrinkled, the upper portion also grooved and ridged longitudinally, each ridge corresponding to one of the fully developed tentacles of the marginal cycle.

Tentacles of the marginal cycle about fifty in number, but difficult to determine, as many were quite small and evidently just developing. It was likewise impossible to enumerate the inner tentacles in a preserved condition as they were crowded together and broke in pieces if any attempt was made to separate them. The animal would not expand fully when alive.

When living the colouration agreed with the description given by Gosse. The column was uniform yellowish white, with a dark olivegreen band at the summit, they area from which they arise white, and upon the base of the tentacles a series of maroon or purple patches. Marginal tentacles slender, not long; light yellowish brown, with indistinct bars of chestnut brown across the inner faces. The oral series very dark maroon.

\section{LITERATURE.}

1860. Gosse, P. H. Actinologia Britannica.

1889. Haddon, A. C. Revision of British Actiniæ, Part I. Proc. R. Dublin Soc.

1889. Cunningham, J. T. Tealia tuberculata. Journ. Mar. Biol. Assoc.

1890. Drxon, G. Y. and A. F. Note on T. tuberculata, etc. Ann. and Mag., Nat Hist., Vol. V.

1891. Carlgren, O. Das genus Bolocera. Öfr. Kongl. Svensk. Vet. Akad.

1891. Haddon, A. C., and Shackleton, A. M., Rev. Brit. Actiniæ, Part II. Proc. R. Dublin Soc.

1893. Carlgren, O. Studien uber Nordische Actinien. Svenska. Ak. Handl.

1902. " " Olga Actiniaria. Meeresuntersuchungen. Heft I.

1905. Roule, L. Cerianthes d'atlantique nord. 